\title{
Correlation of Age, Nutritional Status, and Smoking Habits with Work Fatigue in Dome Installation Workers
}

\author{
Hubungan Usia, Status Gizi, dan Kebiasaan Merokok dengan Kelelahan Kerja \\ pada Pekerja Pemasangan Kubah
}

\author{
Tazkia Salsabila, Mulyono \\ Department of Occupational Safety and Health, Faculty of Public Health Universitas Airlangga \\ Campus C Mulyorejo, Surabaya, East Java 60115
}

\begin{abstract}
Introduction: All works have the potential to cause work fatigue, one of which is in the dome installation work. Work fatigue leads to decreased work capacity and endurance to work. Factors causing work fatigue are age, sex, nutritional status, smoking habits, history of illness, work environment, workload, work hours, and rest periods. This study aims to find out the correlation between age, nutritional status, and smoking habits with work fatigue in dome installation workers at PT. A. Methods: This type of research was an observational analytic research using a cross-sectional approach. This study had a population of all employees of PT. A in the dome installation section. The samples used were 33 workers, taken using total sampling. This study was conducted in 2020. This study used variables of age, nutritional status, smoking habits, and work fatigue. Instrument for collecting data was a questionnaire. The Industrial Fatigue Research Committee (IFRC) questionnaire was specifically used to collect data on work fatigue. In addition, data on nutritional status were obtained from the calculation of Body Mass Index (BMI). The contingency coefficient was used to analyze the data. Results: The workers mostly $(81.8 \%)$ experienced mild work fatigue and were aged $\leq 35$ years, had normal nutritional status, and were mild smokers. Conclusion: There was a weak relationship between age and nutritional status with work fatigue and a very weak relationship between smoking habits with work fatigue.
\end{abstract}

Keywords: age, nutritional status, smoking habits, work fatigue

\section{ABSTRAK}

Pendahuluan: Semua pekerjaan berpotensi untuk terjadinya kelelahan kerja, salah satunya yaitu pekerjaan pemasangan kubah. Kelelahan kerja mengakibatkan penurunan kapasitas kerja dan ketahanan tubuh untuk bekerja. Terdapat berbagai faktor penyebab kelelahan kerja yaitu usia, jenis kelamin, status gizi, kebiasaan merokok, riwayat penyakit, lingkungan kerja, beban kerja, waktu kerja, dan waktu istirahat. Penelitian ini bertujuan untuk mengetahui hubungan antara usia, status gizi, dan kebiasaan merokok dengan kelelahan kerja pada pekerja pemasangan kubah PT. A. Metode: Jenis penelitian ini adalah observasional analitik yang menggunakan pendekatan cross sectional. Penelitian ini memiliki populasi seluruh pekerja PT. A bagian pemasangan kubah. Sampel yang digunakan yaitu sebanyak 33 orang diambil dengan menggunakan total sampling. Penelitian ini dilakukan pada tahun 2020. Penelitian ini menggunakan variabel usia, status gizi, kebiasaan merokok, dan kelelahan kerja. Instrument pengumpulan seluruh data menggunakan kuesioner. Kuesioner Industrial Fatigue Research Committee (IFRC) digunakan untuk mengumpulkan data mengenai kelelahan kerja. Selain itu, data mengenai status gizi akan didapatkan dari perhitungan Indeks Massa Tubuh (IMT). Data tersebut akan dianalisis dengan menggunakan uji koefisien kontingensi. Hasil: Penelitian ini mendapatkan hasil pekerja sebanyak 27 orang (81.8\%) mengalami kelelahan kerja rendah. Pekerja yang paling banyak mengalami kelelahan kerja rendah yaitu pekerja berusia $\leq 35$ tahun, memiliki status gizi normal, dan termasuk perokok ringan. Simpulan: Terdapat hubungan yang lemah antara usia dan status gizi dengan kelelahan kerja dan hubungan yang sangat lemah antara kebiasaan merokok dengan kelelahan kerja.

Kata kunci: kebiasaan merokok, kelelahan kerja, status gizi, usia

Corresponding Author:

Tazkia Salsabila

Email: tazkia.salsabila-2016@fkm.unair.ac.id

Telephone: +6282166323825

\section{INTRODUCTION}

Indonesia, as one of the developing countries, is doing development in various sectors, one of which is in the construction sector. Construction sector is one of the occupational sectors with a 
high risk of hazard. This is because it has several characteristics such as multi-disciplinary, a large number of workers, limited working period, a high work intensity, and a variety of work equipment. Based on the BPJS Ketenagakerjaan (2019) data in 2018, work accidents in Indonesia reached 173,105 and were dominated by work accidents in the construction sector. Rijanto (2010) further classifies construction works that have a high risk of workers falling from height into 5 groups, one of which is roofing work.

PT. A is a company that specializes in roof construction, such as domes. The work process includes fabrication process to the dome installation process. In the dome installation process, the work intensity is high because it is done manually. The dome installation work is carried out at height that has a high potential hazard for workers falling from the height. This work is also done outdoors, so workers are exposed to direct sunlight. Sometimes workers do welding which also makes them exposed to heat from the welding process. During work at heights it is not uncommon for workers to work with unnatural work attitudes. In addition, workers often work late until night to be able to complete work on time according to the predetermined targets. These conditions can cause health problems for workers.

Based on the initial survey and interview with the person in charge of the dome installation project, it is found that the health problem often experienced by workers is work fatigue. The most frequent reason for not coming to work is pain due to fatigue. Almost every month there are workers who do not come to work because of pain due to work fatigue.

A health problem that often occurs in workers of all types of work is work fatigue. International Labour Organization (2013) data shows the fatigue has caused two million workers to die almost every year. The study states that based on the results of a total sample of 58,115 there were 18,828 or $32.8 \%$ of workers experiencing fatigue. According to Triyunita, Ekawati and Lestantyo (2013), more than $65 \%$ of workers in Indonesia came to the company clinic with complaints of work fatigue.

Fatigue is a protective mechanism to enable the body to avoid further damage, and restoration can occur following resting (Tarwaka, 2015). High fatigue causes workers to no longer be able to work and if they remain forced, fatigue will increase and disrupt the smooth work and have a negative impact on the health of workers (Suma'mur, 2014).
Work fatigue is also shown to cause $60 \%$ or more of accidents at workplace (Maurits, 2010).

Work fatigue can be caused by various factors. Maurits (2010) claims that the contributing factors of work fatigue are nutritional status, history of illness, work climate, noise, lighting, and workload. In addition, Tarwaka, Bakri, and Sudiajeng (2004), meanwhile, state that work fatigue is caused by age, gender, smoking habits, work hours, and rest periods.

This study focuses on age as one contributing factor of the occurence of work fatigue. Older people will experience changes in physical strength. In general, someone who is approaching 45 years old will experience a decrease in muscle strength (Maurits, 2010). Based on research by Amalia and Widajati (2019), age and work fatigue had a relationship $(\mathrm{p}<0.05)$. The study found that mild and moderate work fatigue was most experienced by workers aged $36-50$ years.

In addition, nutritional status has a very close relationship with health and work power. Workers with a good nutritional status are expected to be able to maintain work ability and increase work productivity (Suma'mur, 2014). If the workers have poor nutritional status even at a mild level, work performance and concentration will decrease, and it can increase work fatigue (Ministry of Health, 2011). Research by Deyulmar, Suroto and Wahyuni (2018) shows the statistical test got a significance value of $p<0.05$, so work fatigue was affected by age. The research found that work fatigue was experienced by workers who had abnormal nutritional status includingunderweight, overweight, and obese condition.

Smoking habit is another contributing factor to work fatigue. This is related to the worker's fitness condition. The longer and the higher the level of smoking habits, the higher the complaints in the muscles (Tarwaka Bakri, and Sudiajeng, 2004). Research done by Sartono, Martaferry and Winaresmi (2016) found that smoking habits influenced the occurence of work fatigue $(p<0.05)$. The research shows that severe work fatigue was most experienced by workers who had smoking habits compared to workers who did not have smoking habits.

Based on the conditions of work and the results of previous studies, this study has the objective to determine the correlation between age, nutritional status, and smoking habits with work fatigue in dome installation workers. 


\section{METHODS}

This study was included in the observational analytic research because the data retrieval was done without any treatment of objects and variables, and it aimed to determine the relationship among the independent and the dependent variables. Crosssectional was the research design used because it was done in a definite period.

This research was conducted in one of the mosque dome installation projects at PT. A. Data collection was done in June 2020. All employees of PT. A at the dome installation section (33 workers) became the population in this study. The number of samples in this study was 33 workers with the sampling technique using total sampling.

This study used independent and dependent variables. The variables included in the independent variables were age, nutritional status, and smoking habits. Meanwhile, work fatigue was the dependent variable.

Instrument for data collection on all variables was a questionnaire. Specifically, data on age were obtained from an open-ended questionnaire, while data on nutritional status were obtained from measurements of Body Mass Index (BMI). In addition, the calculation of the BMI required height and weight data. Therefore, questionnaire sheets consisted of questions about workers' height and weight.

BMI workers were categorized into three, namely underweight, normal, and overweight. Moreover, smoking habits of the workers was measured based on the number of cigarettes consumed in one day. specifically, the smoking habits were categorized into four, which were not smoking, mild smokers (consuming $1-10$ cigarettes per day), moderate smokers (consuming $11-20$ cigarettes per day), and heavy smokers (consuming $>20$ cigarettes per day). Furthermore, to collect data on work fatigue, the questionnaire to be used was the Industrial Fatigue Research Committee (IFRC). The questionnaire consisted of 30 questions consisting of 10 questions ach of which was about weakened activities, weakened motivation, and physical fatigue. Work fatigue in the questionnaire was categorized into three, namely mild, moderate, and severe work fatigue.

Data analysis techniques used in this study were univariate and bivariate analyzes. Univariate analysis was performed to find out the frequency distribution of the variables. Meanwhile, to determine the correlation between variables, the analysis used was bivariate. In addition, the statistical test used to find out the strength of the relationship between variables was contingency coefficient. This research ethical certificate has also obtained a certificate with an ethic code from the Health Research Ethics Committee, Universitas Airlangga number 14/EA/ KEPK/2020.

\section{RESULTS}

\section{Age of the Workers}

From Table 1, it can be discovered that the most dominant age group of workers in the dome installation at PT. A was $\leq 35$ years, comprising 25 workers $(75.8 \%)$. However, there were also workers belonging to the age group of $36-50$ years $(21.2 \%)$ and $>50$ years $(3 \%)$.

\section{Nutritional Status of the Workers}

Referring on Table 2, most of the PT. A dome installation workers had normal nutritional status, comprising 27 workers $(81.8 \%)$. However, there were also workers who had underweight nutritional status $(12.1 \%)$ and overweight nutritional status (6.1\%).

\section{Smoking Habits of the Workers}

Denoting to Table 3, there were more workers who smoked than nonsmokers. The category of most smokers was mild smokers, comprising 18

Table 1. Distribution of Age of Dome Installation Workers at PT. A in June 2020

\begin{tabular}{ccc}
\hline Age (years) & Frequency (n) & Percentage (\%) \\
\hline$\leq 35$ & 25 & 75.8 \\
$36-50$ & 7 & 21.2 \\
$>50$ & 1 & 3 \\
\hline Total & 33 & 100 \\
\hline
\end{tabular}

Table 2. Distribution of Nutritional Status of Dome Installation Workers at PT. A in June 2020

\begin{tabular}{ccc}
\hline $\begin{array}{c}\text { N u t r i t i o n a I } \\
\text { Status }\end{array}$ & Frequency (n) & Percentage (\%) \\
\hline Underweight & 4 & 12.1 \\
Normal & 27 & 81.8 \\
Overweight & 2 & 6.1 \\
\hline Total & 33 & 100 \\
\hline
\end{tabular}


Table 3. Distribution of Smoking Habits of Dome Installation Workers at PT. A in June 2020

\begin{tabular}{ccc}
\hline Smoking Habits & Frequency (n) & Percentage (\%) \\
\hline Not smoking & 6 & 18.2 \\
Mild smokers & 18 & 54.5 \\
Moderate smokers & 9 & 27.3 \\
\hline Total & 33 & 100 \\
\hline
\end{tabular}

Table 4. Distribution of Work Fatigue of Dome Installation Workers at PT. A in June 2020

\begin{tabular}{ccc}
\hline Work Fatigue & Frequency (n) & Percentage (\%) \\
\hline Mild & 27 & 81.8 \\
Moderate & 6 & 18.2 \\
\hline Total & 33 & 100 \\
\hline
\end{tabular}

Table 5. Cross Tabulation between Age and Work Fatigue of Dome Installation Workers at PT. A in June 2020

\begin{tabular}{cccccccc}
\hline \multirow{2}{*}{$\begin{array}{c}\text { A g e } \\
\text { (years) }\end{array}$} & \multicolumn{4}{c}{ Mork Fatigue } & \multicolumn{2}{c}{ Mild } & \multicolumn{2}{c}{ Moderate } & & \multicolumn{1}{c}{$\begin{array}{c}\text { Contingency } \\
\text { Coefficient }\end{array}$} \\
\cline { 2 - 6 } & $\mathbf{n}$ & $\mathbf{\%}$ & $\mathbf{n}$ & $\mathbf{\%}$ & $\mathbf{N}$ & $\mathbf{\%}$ & \\
\hline$\leq 35$ & 19 & 76 & 6 & 24 & 25 & 100 & \\
$36-$ & 7 & 100 & 0 & 0 & 7 & 100 & 0.258 \\
50 & & & & & & & \\
$>50$ & 1 & 100 & 0 & 0 & 1 & 100 & \\
\hline Total & 27 & 81.8 & 6 & 18.2 & 33 & 100 & \\
\hline
\end{tabular}

workers $(54.5 \%)$. Meanwhile, the rest were moderate smokers $(27.3 \%)$ and not smoking (18.2\%).

\section{Work Fatigue of the Workers}

From Table 4, it can be concluded that PT. A dome installation workers experienced mild work fatigue the most, comprising 27 workers (81.8\%). Meanwhile, the rest experienced moderate work fatigue $(18.2 \%)$.

\section{Correlation between Age and Work Fatigue}

Table 5 shows that mild work fatigue was mostly experienced by workers aged $\leq 35$ years, comprising 19 people $(76 \%)$. Furthermore, in the age group of 36 - 50 years and $>50$ years, all workers were also noted to experiencemild work fatigue, yet with much smaller number, comprising 7 workers and 1 worker respectively (100\% each). Interestingly, Moderate work fatigue occurred entirely in workers in the age group of $\leq 35$ years $(100 \%)$.

\section{Correlation between Nutritional Status and Work Fatigue}

Table 6 represents that mild work fatigue mostly affected workers with normal nutritional status, comprising 21 workers (77.8\%). Furthermore, all workers with underweight and overweight nutritional statuswere also noted to experience mild work fatigue, comprising 4 workers and 2 workers

Table 6. Cross Tabulation between Nutritional Status and Work Fatigue of Dome Installation Workers at PT. A in June 2020

\begin{tabular}{|c|c|c|c|c|c|c|c|}
\hline \multirow{3}{*}{ Nutritional Status } & \multicolumn{4}{|c|}{ Work Fatigue } & \multirow{2}{*}{\multicolumn{2}{|c|}{ Total }} & \multirow{3}{*}{$\begin{array}{c}\text { Contingency } \\
\text { Coefficient }\end{array}$} \\
\hline & \multicolumn{2}{|c|}{ Mild } & \multicolumn{2}{|c|}{ Moderate } & & & \\
\hline & $\mathbf{n}$ & $\%$ & $\mathbf{n}$ & $\%$ & $\mathbf{N}$ & $\%$ & \\
\hline Underweight & 4 & 100 & 0 & 0 & 4 & 100 & \\
\hline Normal & 21 & 77.8 & 6 & 22.2 & 27 & 100 & 0.217 \\
\hline Overweight & 2 & 100 & 0 & 0 & 2 & 100 & \\
\hline Total & 27 & 81.8 & 6 & 18.2 & 33 & 100 & \\
\hline
\end{tabular}

Table 7. Cross Tabulation between Smoking Habits and Work Fatigue of Dome Installation Workers at PT. A in June 2020

\begin{tabular}{|c|c|c|c|c|c|c|c|}
\hline \multirow{3}{*}{ Smoking Habits } & \multicolumn{4}{|c|}{ Work Fatigue } & \multirow{2}{*}{\multicolumn{2}{|c|}{ Total }} & \multirow{3}{*}{$\begin{array}{c}\text { Contingency } \\
\text { Coefficient }\end{array}$} \\
\hline & \multicolumn{2}{|c|}{ Mild } & \multicolumn{2}{|c|}{ Moderate } & & & \\
\hline & $\mathbf{n}$ & $\%$ & $\mathbf{n}$ & $\%$ & $\mathbf{N}$ & $\%$ & \\
\hline Not smoking & 4 & 66.7 & 2 & 33.3 & 6 & 100 & \\
\hline Mild smokers & 15 & 83.3 & 3 & 16.7 & 18 & 100 & 0.191 \\
\hline Moderate smokers & 8 & 88.9 & 1 & 11.1 & 9 & 100 & \\
\hline Total & 27 & 81.8 & 6 & 18.2 & 33 & 100 & \\
\hline
\end{tabular}


respectively (100\% each). Interestingly, moderate work fatigue was being suffered entirely by workers with normal nutritional status (100\%).

\section{Correlation between Smoking Habits and Work Fatigue}

Table 7 indicates that mild work fatigue was mostly experienced by workers belong to the category of mild smokers $(83.3 \%)$. Furthermore, most of nonsmokers and moderate smokers were also noted to experiencemild work fatigue, comprising 8 workers and 4 workers respectively. Likewise, moderate work fatigue was also suffered by mild smokers the most, comprising 3 workers (50\%).

\section{DISCUSSION}

\section{Age of The Workers}

The results show that most of the workers at PT. A in the dome installation section were aged $\leq$ 35 years. However, there were also workers aged $36-50$ years and $>50$ years. Specifically, 19 years old was the youngest age, while 53 years old was the oldest age of the workers. The fact that there were more workers aged $\leq 35$ years shows that companies have paid attention to their workers well, considering that the dome installation work is included in the work with a high risk.

Age affects the physical strength of workers as the physical strength changes following age. However, this can be balanced by mental maturity and experience (Maurits, 2010). Changes in organs, cardiovascular system, hormonal system, and others also occur in the later age (Suma'mur, 2014). Therefore, work performed by older workers should not require muscle strength, endurance, speed, and flexibility (Tarwaka, Bakri and Sudiajeng, 2004).

\section{Nutritional Status of the Workers}

The results showthat the workers of PT. A in the dome installation had a different nutritional status. This difference in nutritional status occurred because the company did not provide lunch or snack facilities so workers had to buy their own food. This caused workers to buy the desired food freely and caused energy intake with energy needs to become unbalanced.

Nutritional status is in fact determined based on the fulfillment of the needs of nutrients derived from food. The nutrients needed by the body include carbohydrates, proteins, fats, vitamins, mineral, and water. These nutrients will be digested and will produce energyneeded when doing work (Suma'mur, 2014). In order that work capacity is not disrupted, intake and energy expended must be balanced. Therefore, the fulfillment of nutrition is very necessary to maintain and increase the body's resistance to work demands (Tarwaka, Bakri and Sudiajeng, 2004).

The results of the study represent that the nutritional status that most of the workers had was normal. This shows that food consumed by workers has already been appropriate with the energy needed to do work, and the workers have already had a healthy lifestyle. However, there were also workers with underweight and overweight nutritional status. Underweight nutritional status is caused by food consumed less than the energy needed. Meanwhile, overweight nutritional status is caused by excessive consumption of food compared to the energy needed. Both of these problems can reduce the degree of health and work productivity (Tarwaka, Bakri and Sudiajeng., 2004).

\section{Smoking Habits of the Workers}

The results show that most of the workers of PT. A in the dome installation section were smoking. Those workers consumed cigarettes as many as 1 10 cigarettes a day at most, so they were considered mild smokers. Smoking was usually carried out during breaks to fill breaks other than lunch.

A cigarette contains 4000 chemical compounds. The three main chemical compounds in a cigarette are nicotine, tar, and carbon monixide. Nicotine is a dangerous substance that can cause addiction. Moreover, tar is a dangerous substance that can cause cancer (carcinogenic) and other diseases. Meanwhile, carbon monoxide can reduce oxygen levels in the blood because it is a poisonous gas (Ministry of Health, 2012).

The resulting effects of smoking are very diverse on vital organs. One of them is causing cardiovascular disorders. If a person smokes, the oxygen level in the body will decrease. A decrease in oxygen levels will later have an effect when someone is doing work that requires energy (Sartika, Suroto and Ekawati, 2019). In addition, someone who has smoking habits can have a negative impact on physical fitness, so he/she will get tired easily (Sartono, Martaferry and Winaresmi, 2016). 


\section{Work Fatigue of the Workers}

Based on the results obtained from this study, it is found thats mild work fatigue was perceived by workers the most because their work was not monotonous. While doing their work, the workers also did other activities such as walking or sitting and chatting with other co-workers so that there was no feeling of boredom that could cause work fatigue.

The results also show that there were workers who experienced moderate work fatigue. This can happen because the dome installation work has a high enough work intensity. This work is done manually, is carried out at heights which sometimes cause workers to work with unnatural work attitudes, and is carried out outdoors so that workers are exposed to direct sunlight.

Fatigue is felt by someone as a bad mood, mental condition, or body condition (Hockey, 2013). Everyone shows different conditions when experiencing fatigue. In general, symptoms of fatigue start from very mild complaints to very tiring feelings. A common symptom that workers feel when experiencing fatigue is a loss of will to work. If the workers feel tremors or pain in the muscles, then the workers have experienced muscle fatigue (Tarwaka, 2015).

Many factors that induce the occurrence of work fatigue. One of the condition that causes fatigue is the accummulation of feelings inducing fatigue (Suma'mur, 2014). The impact caused by workers experiencing work fatigue is a decrease in work performance, decreased function of motor and neural physiology, unfit body condition, and decreased spirit at work. In addition, work fatigue also causes a decrease in work productivity and increases the occasion of accidents at the workplace (Maurits, 2010).

\section{Correlation between Age and Work Fatigue}

The statistical test of age and work fatigue obtained a value of 0.258 . The value indicates that age and work fatigue had a weak relationship. This study has the same result as a research by Suoth et al. (2017) which showed a weak relationship between age and work fatigue $(\mathrm{r}=0.305)$. Their research represented that the workers were mostly aged 35-50 years and experienced mild work fatigue. Besides, a research done by Khasanah, Suwaji and Kurniawan (2016) showed a weak relationship between age and complaints of work fatigue $(r=0.364)$. Those research showed that the age group of 36-45 years was the one who experienced severe work fatigue the most.

In this study, age and work fatigue had a weak relationship because dome installation workers were dominated by workers aged $\leq 35$. This is in accordance with Tarwaka et al. (2004), suggesting that a person's capacity reaches its peak when aged $25-30$ years. Therefore, most of these workers only experienced mild work fatigue.

The weak relationship between age and work fatigue is also caused by the fact that workers aged $>50$ years only experienced mild work fatigue. Older workers do not rule out the possibility of experiencing mild work fatigue because the older have more work experience in getting around so as not to experience severe work fatigue (Juliana, camelia and Rahmiwati, 2018). Moreover, older workers have more experience and more stable emotions compared to younger workers, so older workers can work better (Ekawati, Rahmawati and Wijaningsih, 2016). Older workers also have a higher level of work productivity than the younger workers do (Maurits, 2010). In this study, dome installation workers were able to utilize the given break time so well that the level of work fatigue experienced was only mild. This is consistent with research conducted by Tenggor, Pondaag and Hamel (2019) stating that older workers did not experience work because workers were able to make good use of their break time.

According to Crawford et al. (2016), age is not the only factor affecting work ability. It depends on the nature of the work demands. This is further reinforced by Wahyuni and Indriyani (2019) suggesting that work fatigue can be experienced by all working age groups and not only by certain age groups.

\section{Correlation between Nutritional Status and Work Fatigue}

The value of the statistical test of nutritional status and work fatigue was 0.217 . This value indicates that nutritional status and work fatigue had a weak relationship. A research by Suryaningtyas and Widajati (2017) has the same result as this study, stating that the relationship between nutritional status and work fatigue was weak $(r=0.341)$. The research found that most workers had normal nutritional status. Workers with normal nutritional status felt less tired the most, while workers with underweight and overweight nutritional status mostly felt very 
tired. Research conducted by Witjaksani and Darnoto (2018) also showed that nutritional status and work fatigue had a weak relationship ( $\mathrm{r}=0.323$ ). Their results showed that there was quite a lot of workers who had normal nutritional status and suffered from moderate work fatigue.

Moreover, nutritional status and work fatigue had a weak relationship because most of the dome installation workers had normal nutritional status. According to Verawati (2016), workers with good nutritional status had normal body conditions so that they were able to recover the body from work fatigue well. Wahyuni and Indriyani (2019) also said that good nutritional status was a determinant of workers' work productivity. This study found that workers with normal nutritional status only had a mild work fatigue. In addition, based on the results of this study, workers with normal nutritional status also experienced moderate work fatigue. According to research conducted by Atiqoh, Wahyuni and Lestantyo (2014), most workers with normal nutritional status often suffered from severe work fatigue because it was influenced by other individual characteristic factors, like age and working period.

The weak relationship between nutritional status is also caused by the fact that in this study workers with underweight and overweight nutritional status only experienced mild work fatigue. According to Komalig and Kawoka (2018), this can happen because work fatigue is not only influenced by nutritional status but there are still other factors that can affect work fatigue such as age, workload, and work environment. This is in accordance with the results of this study where most dome installation workers were aged $\leq 35$ years old, or it can be said that workers were still at the productive age and the physical capacity of workers was still at its peak. The research conducted by Oktariani, Rakhma and Kurniawan (2019) also said that nutritional status did not affect the occurrence of work fatigue because most of the workers were aged $<40$ years old.

\section{Correlation between Smoking Habits and Work Fatigue}

The relationship value of smoking habits and work fatigue was 0.191 . This value denotes that the relationship between smoking habits and work fatigue was very weak. This indicates the same result as research done by Prastuti and Martiana (2016), suggesting that the relationship between smoking habits and work fatigue was very weak $(\mathrm{r}=0.008)$. That previous study indicated that most workers who smoked experienced work fatigue. However, this study does not have the same result as research done by Syamsuddin and Gerung (2018) stating that smoking habits with complaints of fatigue had a strong enough relationship.

In this study, smoking habits and work fatigue had a very weak relationship because smoking has already become a habit for dome installation workers and they also felt uncomfortable when they did not smoke. This is in accordance with the research by Dirgayudha (2014) stating that smoking is a habit because workers start smoking when they are in their teens and have done it repeatedly. According to Hermawan, Soebijanto and Haryono (2017), smoking habits does not affect work fatigue because smoking can give positive suggestions to workers. Prastuti and Martiana (2016) further state that smoking can make workers more confident and more concentrated while working and can reduce fatigue, stress, and boredom. Gaghiwu, Josephus and Rizald (2016) also state that smoking activity is considered as a stimulus to encourage workers to work.

The very weak relationship between smoking habits and work fatigue is caused by the fact that in this study most workers were mild smokers and these workers only suffered from mild work fatigue. Febriyanto, Gunawan and Amalia (2019) found that most of the workers were mild smokers, meaning that workers consumed 1 to 10 cigarettes a day, so smoking did not affect work fatigue.

This study also obtained a result that work fatigue was mostly experienced by workers who smoked compared to workers who did not smoke. Smoking can cause a decrease in lung capacity so that the ability to consume oxygen is reduced. The low oxygen content in the blood can inhibit the burning of carbohydrates and cause a buildup of lactic acid. This eventually causes pain in the muscles. If a worker has to do his work by exerting his energy, he becomes easily exhausted (Tarwaka, Bakri and Sudiajeng, 2004).

\section{CONCLUSION}

Based on research conducted at PT. A in the dome installation section, it can be concluded that most workers aged $\leq 35$ years, had normal nutritional status, categorized as mild smokers, and experienced mild work fatigue. The strength of the correlation between age and nutritional status with work fatigue was weak. Meanwhile, the correlation between smoking habits and work fatigue was very weak. 


\section{ACKNOWLEDGEMENTS}

Thanks to Allah SWT that the author is finally able to accomplish the study. The author would also thank the owner of the company and all of the workers, especially the dome installation workers, who have agreed to be the respondents in this study. Finally, gratitude is given to family and friends who have given their support and help so that this research can be finished well.

\section{REFERENCES}

Amalia, I. and Widajati, N. (2019) ‘Analisa Kelelahan Kerja Secara Obyektif Berdasarkan Reaction Timer pada Tenaga Kerja Unit Pengerolan Besi PT X', Journal of Health and Science Prevention, 3(1), pp. 16-24.

Atiqoh, J., Wahyuni, I. and Lestantyo, D. (2014) 'Faktor-Faktor yang Berhubungan dengan Kelelahan Kerja pada Pekerja Konveksi Bagian Penjahitan di CV. Aneka Garment Gunungpati Semarang', Jurnal Kesehatan Masyarakat (e-Journal), 2(2), pp. 119-126.

Badan Penyelenggara Jaminan Sosial Ketenagakerjaan (BPJS Ketenagakerjaan) (2019) Angka Kecelakaan Kerja Cenderung Meningkat, BPJS Ketenagakerjaan Bayar Santunan Rp1,2 Triliun. Jakarta: BPJS Ketenagakerjaan.

Crawford, J. O. et al. (2016) The Ageing Workforce: Implications for Occupational Safety and Health - A Research Review. Executive Summary. Europe: European Agency for Safety and Health at Work.

Deyulmar, B. A., Suroto and Wahyuni, I. (2018) 'Analisis Faktor-Faktor yang Berhubungan dengan Kelelahan Kerja pada Pekerja Pembuat Kerupuk Opak di Desa Ngadikerso, Kabupaten Semarang', Jurnal Kesehatan Masyarakat (e-Journal), 6(4), pp. 278-285.

Dirgayudha, D. (2014) Faktor-Faktor Yang Berpengaruh terhadap Kelelahan Kerja pada Pembuat Tahu di Wilayah Kecamatan Ciputat dan Ciputat Timur Tahun 2014. Undergraduate Thesis. Jakarta: Faculty of Medicine and Health Science, Universitas Islam Negeri Syarif Hidayatullah Jakarta.

Ekawati, H., Rahmawati, A. Y. and Wijaningsih, W. (2016) 'Faktor Determinan Kelelahan Kerja pada Tenaga Penjamah Makanan di Instalasi Gizi RS dr R Soetijono Blora', Jurnal Riset Gizi, 4(2), pp. $1-8$.
Febriyanto, K., Gunawan, M. C. and Amalia, N. (2019) 'Hubungan Kebiasaan Merokok dengan Kelelahan Kerja pada Petugas Pemadam Kebakaran Kota Samarinda', Jurnal Dunia Kesmas, 8(1), pp. 19-24.

Gaghiwu, L., Josephus, J. R. and Rizald M., R. (2016) 'Analisis Beberapa Faktor Penyebab Kelelahan Kerja pada Tenaga Kerja Bongkar Muat di Pelabuhan Samudera Bitung', Paradigma, 4(1), pp. 59-70.

Hermawan, B., Soebijanto, S. and Haryono, W. (2017) 'Sikap, Beban Kerja, dan Kelelahan Kerja pada Pekerja Pabrik Produksi Aluminium di Yogyakarta', Berita Kedokteran Masyarakat (BKM Journal of Community Medicne and Public Health), 33(4), pp. 213-218.

Hockey, R. (2013) The Psychology of Fatigue: Work, Effort, and Control. New York: Cambridge University Press.

International Labour Organization (2013) Keselamatan dan Kesehatan Kerja Sarana dan Produktivitas. Geneva: International Labour Organization.

Juliana, M., Camelia, A. and Rahmiwati, A. (2018) 'Analisis Faktor Risiko Kelelahan Kerja pada Karyawan Bagian Produksi PT. Arwana Anugrah Keramik, Tbk', Jurnal Ilmu Kesehatan Masyarakat, 9(1), pp. 53-63.

Khasanah, I. M., Suwaji and Kurniawan, T. P. (2016) Hubungan Risiko Kerja Berdiri dengan Tingkat Kelelahan Kerja Pada Operator Mesin Tenun PT. Iskandar Indah Printing Textile Surakarta. Universitas Muhammadiyah Surakarta.

Komalig, M. R. and Kawoka, D. (2018) 'Hubungan Status Gizi dengan Kelelahan Kerja pada Buruh di Pelabuhan Laut Kota Manado', Journal of Community and Emergency, 6(2), pp. 104-109.

Maurits, L. S. K. (2010) Selintas Tentang Kelelahan Kerja. Yogyakarta: Amara Books.

Ministry of Health (2011) Pedoman Pemenuhan Kecukupan Gizi Pekerja Selama Bekerja. Jakarta: Direktorat Jendral Bina Kesehatan Masyarakat, Ministry of Health of the Republik of Indonesia.

Ministry of Health (2012) Penyakit Tidak Menular. Jakarta: Direktorat PPTM, P2PL Ministry of Health of the Republik of Indonesia.

Oktariani, R., Rakhma, L. R. and Kurniawan, A. (2019) 'Sarapan Pagi, Status Gizi, dan Kelelahan Kerja pada Karyawan di Brownies Cinta Karanganyar', Jurnal Dunia Gizi, 2(2), pp. 79-84. 
Prastuti, T. N. and Martiana, T. (2016) 'Analisis Karakteristik Individu dengan Keluhan Kelelahan Kerja pada Pengemudi Taksi Di Rungkut Surabaya', The Indonesian Journal of Public Health, 11(1), pp. 64-74.

Rijanto, B. (2010) Pedoman Praktis Keselamatan, Kesehatan Kerja, dan Lingkungan Kerja (K3L) Industri Konstruksi. Jakarta: Mitra Wacana Media.

Sartika, L., Suroto and Ekawati (2019) 'Hubungan antara Durasi Kerja, Beban Kerja Fisik, dan Beban Kerja Mental Terhadap Kebugaran Jasmani pada Pekerja Konstruksi PT. X Kota Semarang', Jurnal Kesehatan Masyarakat (e-Journal), 7(4), pp. 61-66.

Sartono, Martaferry and Winaresmi (2016) 'Hubungan Faktor Internal dan Faktor Eksternal Karyawan Dengan Kelelahan Kerja pada Karyawan Laundry Garment di Bagian Produksi CV. Sinergie Laundry Jakarta Barat Tahun 2013', Artikel Kesehatan Masyarakat, 1(1), pp. 64-72.

Suma'mur, P. K. (2014) Higiene Perusahaan dan Kesehatan Kerja (HIPERKES). Edisi 2. Jakarta: CV Sagung Seto.

Suoth, L. F., Pinontoan, O. R. and Doda, D. V. (2017) 'Hubungan antara Umur, Status Gizi, dan Beban Kerja Fisik dengan Kejadian Kelelahan Kerja pada Pekerja di PT. Nichindo Manado Suisan', KESMAS, 6(2), pp. 1-15.

Suryaningtyas, Y. and Widajati, N. (2017) 'Iklim Kerja dan Status Gizi dengan Kelelahan Kerja pada Pekerja di Ballast Tank Bagian Reparasi Kapal PT. X Surabaya', Jurnal Manajemen Kesehatan Yayasan RS Dr. Soetomo, 3(1), pp. 31-46.

Syamsuddin, M. Z. and Gerung, J. (2018) 'FaktorFaktor yang Berhubungan dengan Kelelahan
Kerja pada Pekerja Meubel di Kecamatan Poasia Kota Kendari', Jurnal MJPH, 1(2), pp. 1-12.

Tarwaka (2015) Ergonomi Industri: Dasar-Dasar Pengetahuan Ergonomi dan Aplikasi di Tempat Kerja. Edisi 2. Surakarta: Harapan Press.

Tarwaka, Bakri, S. H. A. and Sudiajeng, L. (2004) Ergonomi untuk Keselamatan, Kesehatan Kerja, dan Produktivitas. Surakarta: UNIBA Press.

Tenggor, D., Pondaag, L. and Hamel, R. S. (2019) 'Faktor-Faktor yang Berhubungan dengan Kelelahan Kerja pada Pekerja di Ruang Rawat Inap Rumah Sakit Umum GMIM Pancaran Kasih Manado', e-Journal Keperawatan, 7(1), pp. 1-8.

Triyunita, N., Ekawati and Lestantyo, D. (2013) 'Hubungan Beban Kerja Fisik, Kebisingan, dan Faktor Individu dengan Kelelahan Pekerja Bagian Weaving PT. X Batang', Jurnal Kesehatan Masyarakat Universitas Diponegoro, 2(2), pp. $1-11$.

Verawati, L. (2016) 'Hubungan Tingkat Kelelahan Subjektif dengan Produktivitas pada Tenaga Kerja Bagian Pengemasan di CV Sumber Barokah', The Indonesian Journal of Occupational Safety and Health, 5(1), pp. 51-60.

Wahyuni, D. and Indriyani, I. (2019) 'Faktor-Faktor yang Berhubungan dengan Kelelahan Kerja pada Pekerja Bagian Produksi di PT. Aantam Tbk. UBPP Logam Mulia', Jurnal Ilmiah Kesehatan, 11(1), pp. 73-79.

Witjaksani, A. D. and Darnoto, S. (2018) 'Hubungan antara Beban Kerja dengan Keluhan Low Back Pain (LBP) pada Kuli Panggul Perempuan di Pasar Legi Surakarta', in Proceeding of The URECOL, pp. 487-492. 